\title{
Effects of Climatic Influence on Sweet Potato (Ipomea batatas) Production in Cross River State, Nigeria
}

\author{
Oniah Monday Olah \\ Department of Agricultural Economics/Extension, Cross River University of Technology (CRUTECH), Obubra Campus, Nigeria \\ Email address: \\ oniahmon@yahoo.com \\ To cite this article: \\ Oniah Monday Olah. Effects of Climatic Influence on Sweet Potato (Ipomea batatas) Production in Cross River State, Nigeria. American \\ Journal of Environmental and Resource Economics. Vol. 4, No. 3, 2019, pp. 116-120. doi: 10.11648/j.ajere.20190403.15
}

Received: March 14, 2019; Accepted: August 6, 2019; Published: September 2, 2019

\begin{abstract}
The study examined the effect of climatic variations influencing sweet potato production in Cross River State, Nigeria in the 2018 cropping season. The study described the socio-economic characteristics of the sweet potato farmers in the study area, identify major climatic factors influencing sweet potato production in the study area, assessed the perceptions of sweet potato farmers on the effects of climatic variations on sweet potato production, and identified measures adopted by sweet potato farmers to improve on its production in the study area. Multi-stage sampling procedure was used to select 200 respondents for the study. Structured questionnaire was used to collect primary data from the farmers. Frequency tables, percentages, means, chi-square $\left(\mathrm{X}^{2}\right)$ and the likert scale were used to achieve the study objectives. Findings revealed that $62 \%$ of the respondents were males, $67 \%$ of them were between $21-50$ years of age while $61 \%$ are married. It also indicated that, $54 \%$ had a household size of $1-5$ persons, $76 \%$ had formal education and $63 \%$ of them had sweet potato farming experience of between 6-15 years. On climate variation influence, the study revealed that $76 \%$ of the respondents agreed that they perceived climate variation effects on their sweet potato farms. The chi-square results showed that there were perceived significant $(p<0.05)$ climate influence on sweet potato production in the study area. The major climatic elements observed to express serious constraints in sweet potato production in the area were rainfall, temperature, sunshine, relative humidity and flooding as these variables created problems ranging from irregular rainfall pattern, rotting of sweet potato tubers, low soil moisture, early or late cessation of rainfall, water-logging, flooding and erosion. Remedial measures on climate variation influences include; inter-crop sweet potato with other crops, plant sweet potato on ridges and on big mounds, plant early maturity sweet potato and disease resistant varieties. The study recommends that the farmers should adopt cultural farming practices like mulching to conserve the soil moisture, plant tolerant and improved resistant varieties of sweet potato to drought while irrigation scheme for water supply be provided to ensure water supply to the crop at appropriate time.
\end{abstract}

Keywords: Climate Influence, Sweet Potato Production, Remedial Measures

\section{Background of the Studyand Problem Statement}

Sweet Potato (Ipomoea batatas.) is a dicotyledonous crop that grows well in tropical andsubtropical areas and even in some temperatezones of the developing world. Sweet potato ranks fifth economicallyafter rice, wheat, maize, and cassava, sixth in drymatter content, seventh in digestible energy and ninth in protein content [1]. The studies $[2,3]$ noted that the crop grows well between the temperature range of $15^{\circ} \mathrm{C}$ to $35^{\circ} \mathrm{C}$; with an optimum of $24^{\circ} \mathrm{C}$, anannual rainfall of 750 $1000 \mathrm{~mm}$, with a minimum of $500 \mathrm{~mm}$ in the growingseason.
A well-drained fertile soil rich in organic matter content and a $\mathrm{pH}$ range of 4.5-7.0 is suitable for its cultivation.

In Africa, sweet potato is increasingly becoming an important economic crop among the rural poor even though it is traditionally cultivated. The crop is now widely grown as an important staple food in many African countries including Gambia, Ghana and Nigeria where it is grown by peasant and small holder farmers [4]. The wide range of ecological zones across Cross River state allows for a variety of food and cash crops to be produced [5]. Nevertheless, food production has not kept pace with population increase resulting to a wide gap between food supply and demand.

Studies by the study [6] reported that unlike Kenya, 
Rwanda and Uganda that produced sweet potato on a large scale which had important contribution to house hold food security and farm income, many of the developing economies are still battling with how to exploit their agro biodiversity to contain with the fragile lands and persistent environmental stress. They also observed that small scale farmers in Central Cross River State who produced sweet potato make marginal gains from sweet potato farming, butlarge scale commercial production has not been recorded even though the potentials exist to produce the crop.

The influence of climate variation on agricultural production in Nigeria has received limited attention despite the fact that over $60 \%$ of the active populations of Nigerian are farmers. Studies on climate variation globally andin Nigeria in particular have reasoned that the potential impact of climate variation will include every aspect of the four dimensions of food security; which are food availability, food accessibility, food stability and food utilization [7]. The study [8] noted that educating farmers to achieve food security is a task for all stake holders in the food production sector if the millennium development goal for food for all by the year 2020 must be realized in Nigeria. The research [9] asserted that agro-meteorological services are helping nearly one million farmers in Zambia to become more resilient by providing regularweather forecasts and agricultural advice to farming communities to help them adjust to the types and varieties of crops they grow to suit the weather and boost agricultural production.

The research [10] studied the effects of temporal climate changes on crop production in South-Western Nigeria and found that climate variables had no significant effect on the output of food crops produced within the area. They noted that the adaptation measures used by farmers include planting of resistant varieties, crop rotation and intercropping the crop with other crops. The research [11] examined the effects of climate variation on yam production in Obubra L. G. A of Cross River state, Nigeria andobserved that climate variables influence yam production as reported by the respondents.

International Panel on Climate Change [12] reported that many African countries including Nigeria are likely to be severely affected by climate variation in food crop production because they are highly dependent on agricultural production that is solely practice under hash climatic conditions resulting to low crop yield. It is evident that sweet potato farmers in Cross River State cultivate the crop under rain-fed ecology and so may not be an exception from these climatic threats.
The study therefore, investigated the effects of climate variation on sweet potato production in the study area. Specifically the study determine the socio-economic characteristics of the sweet potato farmers, identify major climatic factors influencing sweet potato production in the study area, examine the perceptions of sweet farmers on the effects of climatic variations on sweet potato production andidentify remedial measures adopted by sweet potato farmers to improve on its production given the vagaries of climatic situations in the area.

\section{Methodology}

\subsection{Study Area}

The study was carried out in Cross River State located in the Niger delta region of in the South - south region of Nigeria. Ecologically, it falls within the tropical rain forest zone of Nigeria. Agriculturally, the state is divided into three agricultural zones in line with the agro climate zones of the state viz, the Northern, the Central and the Southern Agricultural zones. Traditionally, the major occupation of the people is farming though at subsistence level with yam, sweet potato, cassava, plantain, banana, fruits and vegetables cultivated.

The state lies between latitudes $5^{0} 32^{\prime}$ and $4^{0} 27^{\prime}$ North of the Equator and between longitudes $7^{0} 28^{\prime}$ East of the Greenwich meridian and is bounded to the West by Abia and Ebonyi States, to the North by Benue State, to the South by Akwa Ibom state of Nigeria and to the East by the Republic of Cameroon and the Atlantic Ocean [13].

\subsection{Sampling Techniques}

A purposive multistage sampling technique was used to conduct the study. The first stage was the selection of the three (3) agricultural zones in the state. Accordingly, all the three agricultural zones were selected and these are the Southern, the Central and the Northern agricultural zones. The second stage involved the selection of eight (8) Local government areas known to cultivate sweet potato across the agricultural ecological zones; the third stage was the selection of 24 farming communities from the 8LGAs throughthe Extension agents in the study area to form the sample frame. Finally a proportionality factor of $10 \%$ was applied to obtain 200 respondents from the sample frame to form the sample size.

Table 1. Showing the agro climate zones, local government areas, potato farming communities and the respondents.

\begin{tabular}{|c|c|c|c|c|}
\hline Serial Number & Agro climate zone & Local Govt Area & Farming Communities & No of respondents \\
\hline \multirow{11}{*}{1} & \multirow{11}{*}{ Northern Zone } & \multirow{4}{*}{ Obudu } & Ukwutia & 10 \\
\hline & & & Ukpada & 9 \\
\hline & & & Nkirira & 7 \\
\hline & & & Ukpirinyi & 8 \\
\hline & & \multirow{2}{*}{ Ogoja } & Bansara & 7 \\
\hline & & & Ishibori & 8 \\
\hline & & \multirow{5}{*}{ Yala } & Iwang & 6 \\
\hline & & & Okpoma & 11 \\
\hline & & & Ijegu & 7 \\
\hline & & & Ochu & 6 \\
\hline & & & Ukele & 5 \\
\hline
\end{tabular}




\begin{tabular}{|c|c|c|c|c|}
\hline Serial Number & Agro climate zone & Local Govt Area & Farming Communities & No of respondents \\
\hline \multirow{9}{*}{2} & \multirow{9}{*}{ Central Zone } & \multirow{2}{*}{ Abi } & Ekureku & 15 \\
\hline & & & Igbo Imabana & 10 \\
\hline & & \multirow{3}{*}{ Obubra } & Apiapum & 12 \\
\hline & & & Ovonum & 13 \\
\hline & & & Ofodua & 12 \\
\hline & & \multirow{4}{*}{ Yakurr } & Oyadama & 8 \\
\hline & & & Ekori & 4 \\
\hline & & & Nkpani & 7 \\
\hline & & & Idomi & 8 \\
\hline \multirow{4}{*}{3} & \multirow{4}{*}{ Southern zone } & Akamkpa & Awi & 4 \\
\hline & & & Abini & 8 \\
\hline & & Biase & Adim & 10 \\
\hline & & & Akpet Central & 5 \\
\hline Total & & 8 L.G.As & 24 Communities & 200 \\
\hline
\end{tabular}

Source: Field Survey, 2018

\subsection{Method of Data Collection}

The major sources of data collection for this study were primary data. This was done through the use of structured questionnaire and personal interviews. Data were collected on the socio-economic characteristics of the farmers such as age, sex, educational level, family size, marital status and farming experience. Farm output of each farmer was collected per hectare on sweet potato production, the climatic and environmental information affecting sweet potato as perceived by the farmers were also collected. Descriptive statistics, Chi-Square and thelikert scale techniques were used to examine the findings. The Chi- square was used to test whether discrepancies exist between the observed and expected frequencies from those who perceived climate variation in their sweet potato production and those who did not. Expressed as

$$
X^{2}=\frac{\sum\left[(\text { observed frequencies }- \text { expected frequencies })^{2}\right]}{\text { Expected frequencies }}
$$

\section{Results and Discussion}

Table 2. Socio-economic characteristics of sweet potato farmers in the study area.

\begin{tabular}{lll}
\hline Variables & Frequency & Percentage (\%) \\
\hline Gender & 124 & \\
Male & 76 & 62 \\
Female & 200 & 38 \\
Total & & 100 \\
Age (years) & 26 & \\
$<20$ & 80 & 13 \\
$21-30$ & 48 & 40 \\
$31-40$ & 26 & 24 \\
$41-50$ & 20 & 13 \\
51 and above & 200 & 10 \\
Total & & 100 \\
Marital status & 56 & \\
Single & 122 & 28 \\
Married & 10 & 61 \\
Divorced & 12 & 5 \\
Widowed & 200 & 6 \\
Total & & 100 \\
Household size & 108 & 54 \\
$1-5$ & & \\
\hline
\end{tabular}

\begin{tabular}{lll}
\hline Variables & Frequency & Percentage (\%) \\
\hline $6-10$ & 78 & 39 \\
11 and above & 14 & 7 \\
Total & 200 & 100 \\
Educational level & & \\
Never attended school & 48 & 24 \\
Primary school & 42 & 21 \\
Secondary school & 66 & 33 \\
Tertiary school & 44 & 22 \\
Total & 200 & 100 \\
Farming experience & & \\
$1-5$ & 54 & 27 \\
6-10 & 66 & 33 \\
$11-15$ & 60 & 30 \\
16 and above & 20 & 10 \\
Total & 200 & 100 \\
Farm size & & \\
$0.1-0.99$ ha & 154 & 77 \\
$1.0-1.5$ ha & 40 & 20 \\
Above 1.5 ha & 6 & 3 \\
Total & 200 & 100 \\
\hline
\end{tabular}

Source: Field survey, 2018.

From table 2, it reveals that the variable of gender shows that $62 \%$ of the respondents were males while $38 \%$ were females. This result indicates that sweet potato production in the study area is not gender bias, meaning that both males and females are involved in the production of sweet potato in the area. This is in agreement with the findings of the study [8] who reported that $76 \%$ of the sweet potato farmers in Obubra Local Government of Cross River State are males.

The variable of age shows that $40 \%$ of the respondents were within the ages of 21-30 years, while $10 \%$ were 51 years of age and above. The result implies that sweet potato production is carried out by adults who have been in sweet potato production for over some years. This implies that they have experienced and can understand and explain the variations that occur in sweet potato farming due to climate changes. The variable of educational level shows that about $76 \%$ of the respondents had formal education. Given the high levelof educational attainments by the respondents, it is believed that it afforded them the opportunity to perceive any climate influence on their farms on their own. This finding 
agrees with the study [8] who noted that education makes it easier for any individual to critically examine the challenges of production techniques and adapt to other options where available and possible.

The variable of farming experience shows that about $73 \%$ of the sweet potato farmers had a farming experience of 6 years and above. This result indicates that sweet potato farming in the study area is a well-developed enterprise that is engrained into the culture of the people for a long time now. It also implies that the respondents could perceive and observe any climatic changes given their long standing experienced in sweet potato production in the area. The variable of farm size reveals that the sweet potato farmers in the study area are operating at a small-scale level. This is evidenced in the fact that $77 \%$ of the respondents had a farm size of less than a hectare (i.e. 0.1-0.99) of sweet potato farm plots.
Table 3. Response of sweet potato farmers to climate variation in the study area.

\begin{tabular}{lll}
\hline Response & Frequency & Percentages (\%) \\
\hline Yes & 152 & 76 \\
No & 48 & 24 \\
Total & 200 & 100 \\
\hline
\end{tabular}

Source: Field survey, 2018.

Table 3 shows how the respondents perceived effects of climate variation on their sweet potato farms in the study area. The table shows that $76 \%$ of the farmers responded that they perceived somenegative effects of climate variation in their sweet potato farms. This finding agrees with the study [11] who found that about $86 \%$ of the yam farmers observed negative influence of climatic variations on their yam farms in Obubra L. G. A of Cross River State, Nigeria. This finding suggests that yam and sweet potato are vulnerable to variations in climatic conditions in the state.

Table 4. Major climatic elements affecting sweet potato production in the study area.

\begin{tabular}{|c|c|c|c|c|c|c|}
\hline Climate element & Verysevere & Severe & Moderately severe & Not severe & Mean & Rank \\
\hline Rainfall & 118 & 42 & 30 & 10 & 3.34 & $1^{\text {st }}$ \\
\hline Temperature & 82 & 88 & 16 & 14 & 3.19 & $2^{\text {nd }}$ \\
\hline Sunshine & 78 & 63 & 36 & 23 & 2.98 & $3^{\text {rd }}$ \\
\hline Relative humidity & 64 & 44 & 72 & 20 & 2.76 & $4^{\text {th }}$ \\
\hline Flooding & 58 & 68 & 26 & 48 & 2. 68 & $5^{\text {th }}$ \\
\hline Wind & 32 & 42 & 62 & 64 & 2.21 & $6^{\text {th }}$ \\
\hline
\end{tabular}

Source: Field survey, 2018.

Note: Element with Mean $\geq 2.50$ (severe), mean $<2.50$ (not severe)

Table 4 shows that the major climatic elements affecting sweet potato production in the study area as reported by the respondents are rainfall (3.34), temperature (3.19), sunshine (2.98) relative humidity (2.76) and flooding (2.68). Wind did not constitute a severe climatic problem in sweet potato production in the area as this variable had a mean score of less than 2.50 .

Table 5. Chi-square $\left(X^{2}\right)$ analysis of the perceptions of sweet potato farmers on climate variation effects in the study area.

\begin{tabular}{|c|c|c|c|c|c|}
\hline Effects & Observed (o) & Expected (e) & O-E & $(\mathrm{O}-\mathrm{E})^{2}$ & $(\mathrm{O}-\mathrm{E})^{2} / \mathrm{E}$ \\
\hline Influence on yield & 30 & 40 & -10 & 100 & 2.50 \\
\hline Poor growth rate & 28 & 40 & -12 & 144 & 3.60 \\
\hline Reduction in farm income & 32 & 40 & -8 & 64 & 1.60 \\
\hline Pests and diseases outbreak & 18 & 40 & -22 & 484 & 12.10 \\
\hline Rotting of sweet potato tuber & 24 & 40 & -16 & 256 & 6.40 \\
\hline & & & $X^{2}$ & & 26.20 \\
\hline
\end{tabular}

Source: Field survey, 2018.

Table 5 shows the chi-square $\left(\mathrm{X}^{2}\right)$ analysis results on five perceived effects of climatic variation on sweet potato production in the study area. The result revealsthat the calculated value was 26.20 while the tabulated value at $5 \%$ $(p<0.05)$ is 9.49 . This implies that the perceived effect of the climate elements expressed on sweet potato production in the study area were significance. This result agrees with the study [8] who reported a similar significance effect of climate variations on yam production in Obubra L. G. A, Cross River State, Nigeria. The finding also agrees with the position ofthe study [11] that the climatic factors as expressed by the amount of rainfall, sunshine hours, temperature, relative humidity and percentage of moisture in the soil result in yearto-year variability in crop production and is one of the major potential threats to national food security and sustainable agriculture for many African countries.

Table 6. Strategies adopted by sweet potato farmers to adapt to climate variation in the study area.

\begin{tabular}{llll}
\hline & STRATEGIES & $(\mathbf{\%})$ & Rank \\
\hline 1 & Intercrop sweet potato with other crops & 16 & 13 \\
2 & Plant sweet potato varieties tolerant to weather stress & 11 & $1^{\text {st }}$ \\
3 & Plant disease resistant sweet potato varieties & 10 & $2^{\text {nd }}$ \\
4 & Plant sweet potato farmland in rotation with other crops & $3^{\text {rd }}$ & $4^{\text {th }}$ \\
5 & Plant sweet potato in ridges/heaps to retain moisture & $5^{\text {th }}$ \\
\hline
\end{tabular}




\begin{tabular}{llll}
\hline & STRATEGIES & $\mathbf{( \% )}$ & Rank \\
\hline 6 & Plant early maturing sweet potato varieties & 8 & $5^{\text {th }}$ \\
7 & Proper drainage of the farm to control water-logging & $5^{\text {th }}$ & $8^{\text {th }}$ \\
8 & Late planting of sweet potato to check early rain cessation & 7 & $9^{\text {th }}$ \\
9 & Planting of high-yielding sweet potato varieties & 6 & $10^{\text {th }}$ \\
10 & Mulching to reduceheatintensity on the soil & 5 & $11^{\text {th }}$ \\
11 & Increase farm size & 4 & $11^{\text {th }}$ \\
12 & Reduce farm size & 4 & $13^{\text {th }}$ \\
13 & Stop cultivating sweet potato because ofbad weather & 0 & \\
\hline
\end{tabular}

Source: Field survey, 2018.

Table 6 shows the strategies adopted by the sweet potato farmers to adapt to weather changes in sweet potato production in the study area. The first and the most probable strategy are to intercrop sweet potato with other crops, followed by the planting ofsweet potato tolerant to weather stress and planting disease resistant sweet potato varieties. The other remedial measures are planting of sweet potato on rotations and on ridges or heaps so as to retain moisture. None of the respondents supported the option to stop cultivating sweet potato production in the area suggesting that if given the political will and the favourable production environments farmers will produce the crop on a large scale to ensure food security and enhance their household income.

\section{Conclusion and Recommendations}

Based on the results obtained in this study, the study concludes thatsweet potato farmers in the area are small-scale farmers whose productions are affected by the effects of climate variation. Accordingly, the farmers adapted to simple cultural methods to tackle some of the climatic challenges. The study recommends that improved varieties of sweet potato that aretolerant and resistant to bad weather effects be made available to the farmers while irrigation scheme for artificial water supply be constructed by government for the farmers to use in case of adverse weather conditionsduring the farming season.

\section{References}

[1] Food and Agriculture Organization Statistics (2009). FAOS tatistics. http://faostat.fao.org/site/567/default.aspxancor.

[2] Goldsworthy PR, Fisher NM (1984). Thephysiology of tropical field crops. A Wiley Inter-science Publication, Chichester, New York.

[3] Esan and Omilani (2018). Assessment of four Sweet Potato (Ipomoea batatas L.) varieties for adapatibility and productivity in Iwo, Osun State. Asian Journal of Agricultural and Horticultural Research. 1 (1): 1-8, 2018; Article no. AJAHR. 39429.
[4] Stathers, T., Namanda, S., Mwanga, Rom-Khisa, G. and Kapinga, R. (2005). Manual for sweet potato integrated production and pest management of farmer field schools in sub-Saharan Africa. International Potato Center, Kampala, Uganda.

[5] MOFINEWS (2004). Why agriculture in Cross River State: Producing milk and honey for the nation. A B1-Monthly Journal of Finance Incorporated, Calabar Cross River State, Nigeria July - August 2004. vol. 3 No. 6 pp 4-5.

[6] Oniah, M. O, Enya, V. E, Agba, O and Odey, S. O (2007). Analysis of the effects of farm size, labour and capital resources on sweet potato output in Central and Northern Senatorial District of Cross River State, Nigeria. Journal of Agriculture, Forestry and Social Sciences (JOAFES), Vol. 5 No. 3 Pp 58-63.

[7] Food and Agriculture Organisation FAO (2010). Food security and Agricultural Mitigation in Developing Countries. FAO Year Book, 2010. Rome.

[8] Ogbiji, J. E and Oniah, M. O. (2014). Managing education for food security in Nigeria: A case study of sweet potato farmers in Obubra Local Government Area of Cross River State, Nigeria. Journal of Education and Practice, 5 (6): 161-166.

[9] Spore (2019). Weather forecasts: Helping farmers win their battle against climate change. Scaling a higher priority for agriculture. CTANo. 191, December 2018-February 2019.

[10] Oluwasegun, O. A and J. M. Olaniran (2010). Effects of Temporal Changes in Climate Variables on Crop Production in Tropical sub-humid South-western Nigeria. African Journal of Environmental Science and Technology, 4 (8): 500-505.

[11] Oniah, M. O., Kuye, O. O., Ettah, O. I.\&Okon, C. I. (2016). Effects of climate variation on yam production in Obubra Local Government Area of Cross River State, Nigeria. Proceedings of the $17^{\text {th }}$ Annual National Conference of National Association of Agricultural Economists (NAAE), $30^{\text {th }}$ Nov. to $3^{\text {rd }}$ Dec. 2016, Owerri. Pp 876-880.

[12] IPCC (2007). Summary for policy makers in climate change 2007: In: Climate change 2007, impact, adaptation and vulnerability. Contribution of Working Group 11 to the Fourth Assessment Report of the Intergovernmental Panel on climate change. Cambridge University press Cambridge, UK.

[13] Cross River State Survey Division (2004). Map of Cross River State of Nigeria, Ministry of Works, Calabar. 